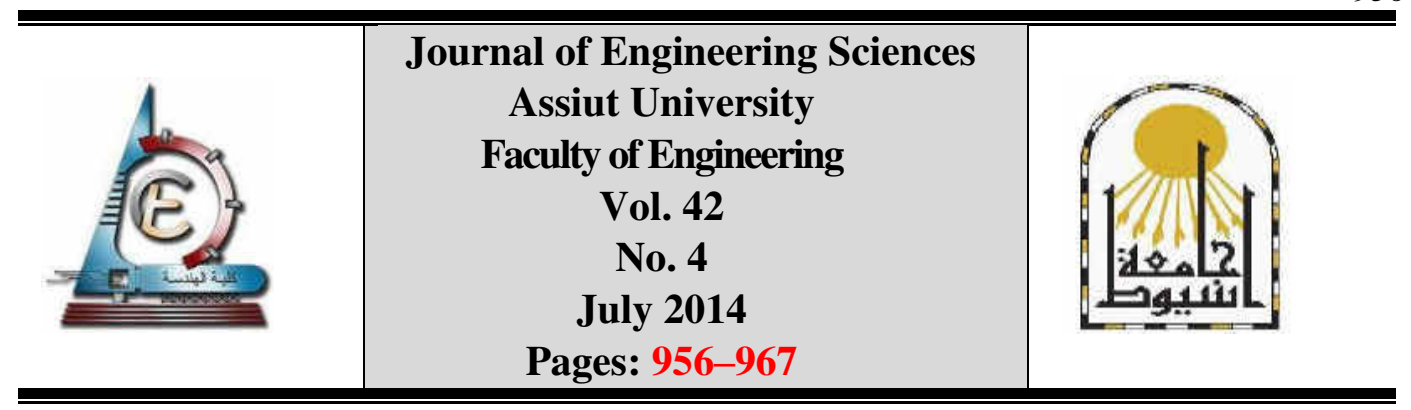

\title{
CONTROL OF LOCAL SCOUR AT A BRIDGE ABUTMENT USING A PROTECTIVE PILE
}

\author{
Elnikhely E.A. \\ Water and Water Str. Eng. Dep., Faculty of Engineering, Zagazig University, Zagazig, Egypt
}

Received 1 July 2014; Accepted 1 August 2014

\begin{abstract}
Various methods are proposed to control scouring around a bridge abutment. In this study, experiments were conducted at a vertical wall abutment in a laboratory flume to explore the effect of using a protective pile installed upstream the abutment for reducing the effects of local scour aroundthe bridge abutment. Tests were conducted with different pile diameters and positions under the same flow conditions. In addition, a 3-D numerical model was used to simulate the scour at the bridge abutment. The model used a finite-volume method to solve the non-transient Navier-Stocks equations and a bed load conservation equation. The $k-\varepsilon$ turbulence model was used to solve the Reynolds-stress term. The 3-D flow model was verified by comparing the obtained results with the experimental results. It was found from this research study that, the optimum case of pile is $(\mathrm{D} / \mathrm{B}=0.125, \mathrm{x} / \mathrm{B}=0.25, \mathrm{~b} / \mathrm{B}=1.0)$, it reduced the relative scour depth by about $41 \%$. The results showed a good agreement between simulation and experimental data. Also, an empirical equation was developed from the experimental results for computing the maximum scour depth at a bridge abutment with a protective pile.
\end{abstract}

Keywords:Scour, bridge abutment, numerical modeling, protective pile.

\section{Introduction}

The scour occurs because of flowing water, excavating and carrying away material from bed and banks of streams and from around the piers and abutmentsof bridges producing scour holes that may cause failure of the bridges. Scour around bridge piers and abutments has resulted in many considerable researches being carried out over the past decade to introduce methods for reducing the scour hole dimensions. Scour around bridge abutment was studied experimentally by Hua [10], Abou-Seida et al.[4], and Kose and Yanmaz[11].Alireza et al.[6] studied the using of oblong collars for reducing the effects of local scour at a bridge pier together with the time aspect of the scour development. Their results indicated that the maximum depth of scour is highly dependent on the experimental duration; it was also observed that, as the size of a collar plate increases, the scour decreases. 
The results from a number of scour surveys using GPR (Ground Penetrating Radar) were presented by Forde et al.[9]. It could be concluded that, GPR surveys should be defined effective in determining both the water depth and sub-bottom geological structure near bridge piers and abutments provided that the correct instrumentation and operational procedures are adopted.Dey and Barbhuiya[7]conducted an experiment to measure the three-dimensional turbulent flow field, using an Acoustic Doppler Velocimeter, at a vertical wall abutment. The data presented would be useful for the development and validation of a flow field model, which can be used for the estimation of scour depth at bridge abutments.Many researches were carried out to minimize the scour dimensions by implementing a circular collar around the pier (Zarrati et al.[26, 27], Alabi [5], AbdelAall and Mohamed [2], and Abdel-Aal et al. [1]).Application of riprap alone and combinations of riprap and collar were examined experimentally by Zarrati et al.[25] for scour control around cylindrical bridge piers. It was concluded that using collar reduced the riprap layer extension in front and sides of the pier.

The flow and local scour variation around single pier and interaction effect between bridge piers were studied by Abouzeid et al.[3] using 3D flow model, It was noticed that the maximum scour depth for circular pier is less than that for rectangular one for both single and double piers cases.

Sui et al.[22] developed an empirical equation describing the equilibrium scour depth of the scour hole around bridge abutments. Numerical and experimental studies were carried out by Mohamed et al.[14]to investigate the effect of different contraction ratios and entrance angles of bridge abutment on local scour depth. Mowafy and Fahmy[16]discussed the effect of constructing two adjacent bridges on the flow characteristics and local scour around bridge piers. Peng et al.[20] presented experiments to investigate the impacts of ice cover on local scour around semicircular bridge abutment; it was found that the maximum scour depth was located $75^{\mathrm{n}} \mathrm{n}$ clined to the flume wall. The flow structure and scour around circular compound bridge piers were investigated experimentally by Kumar et al[12]. Najafzadeh et al.[18] presented new application of group method of data handling (GMDH) to predict scour depth around a vertical pier in cohesive soils, the GMDH network was proved very successful compared to traditional equations. Scour around bridge piers was numerically simulated by Olsen and Melaan[19], Dou [8], Richardson and Panchang[21], and Tseng et al.[24]. In addition, the scour depth and protections around bridge abutments were discussed by Melville [17], Macky[13]. Numerical models were also presented to simulate the scour depth around bridge abutment by Morales and Ettema[15], and Taymaz et al.[23].

In this paper, the local scour around bridge abutment was studied experimentally and numerically. The effect of using a protective pile upstream the abutment wall was examined. The optimum pile diameter for minimum scour depth at the abutment was investigated and the effect of different positions of the pile on the local scour depth was also tested.

\section{Dimensional analysis}

Dimensional analysis is used to define the dimensionless variables based on the selection of all variables governing the scour around bridge abutment in Fig. (1). 
Thedifferent variables controlling the scour upstream the abutment can be classified as follows:

$$
\frac{h_{s}}{y_{t}}=f\left(\frac{D}{B}, \frac{x}{B}, \frac{b}{B}, F_{t}\right)
$$

In which: $\frac{h_{s}}{y_{t}}$ is the relative maximum scour depth; $\frac{D_{B}}{B}$ s the relative diameter of the protective pile; $;$ is the relative positionof pile in $\mathrm{x}$-direction; $\frac{\mathrm{b}}{\mathrm{B}}$ is the relative position of pile in $y$-direction; $F_{t}$ is the tail Froude number; and $y_{t}$ is the tail water depth.

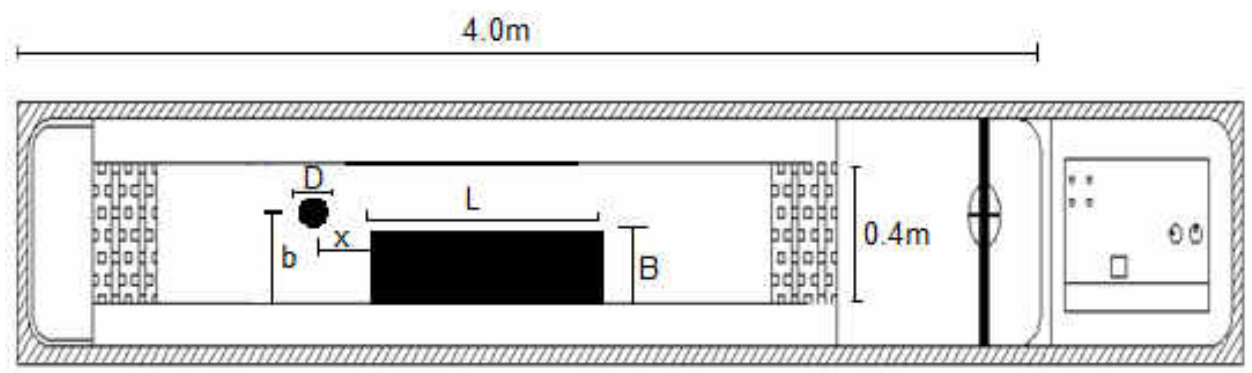

Fig. 1. Schematic diagram of the experimental model

\section{Experimental setup}

Layout of experimental set up is illustrated in Fig. 1.Experiments were conducted in a straight rectangular flume of $0.4 \mathrm{~m}$ wide, $0.20 \mathrm{~m}$ deep and $4.0 \mathrm{~m}$ length, as shown in photo (1), and Fig (1). The laboratory flume was made from a self-colored, glass reinforced plastic mounding. The discharges were measured using a pre-calibrated orifice meter fixed in the main flow line. The tailgate was fixed at the end of the experimental part of the flume; it was used to adjust the tail water depth at the downstream side. The water depths were measured by means of point gauges.

The experimental program can be summarized as following:

- The experimental model within the flume channel was $0.2 \mathrm{~m}$ wide and $0.4 \mathrm{~m}$ Length. The model of bridge abutment was built from wood and was located at the mid length of the flume. The entrance angle of abutment is $90^{\circ}$ see Fig. (1).

- The model sand is non uniform (uniformity coefficient $=\mathrm{D}_{60} / \mathrm{D} 10=1.52<6.0$ ) with $\mathrm{D}_{50}=1.78 \mathrm{~mm}$, and geometric mean standard deviation $=\mathrm{D}_{85} / \mathrm{D}_{15}=1.54$.

- The base case (the abutment without upstream pile) was tested.

- Theprotective pile was fixed upstream the abutment, see Photo (1).It included about 45 experimental runs.

- Different diameters of pile $(\mathrm{D} / \mathrm{B}=0.06,0.125,0.175)$, and different positions of pile $(\mathrm{x} / \mathrm{B}=0.15,0.25,0.35,0.6),(\mathrm{b} / \mathrm{B}=0.5,1.0,1.5)$ were examined.

- The water surface levels were measured along the center line of the flume at the upstream and downstream of the bridge abutment.

- Water surface levels and scour dimensions were measured around the bridge abutment by using an ordinary point gauge (of $\pm 0.1 \mathrm{~mm}$ accuracy) which was mounted on a carriage. 

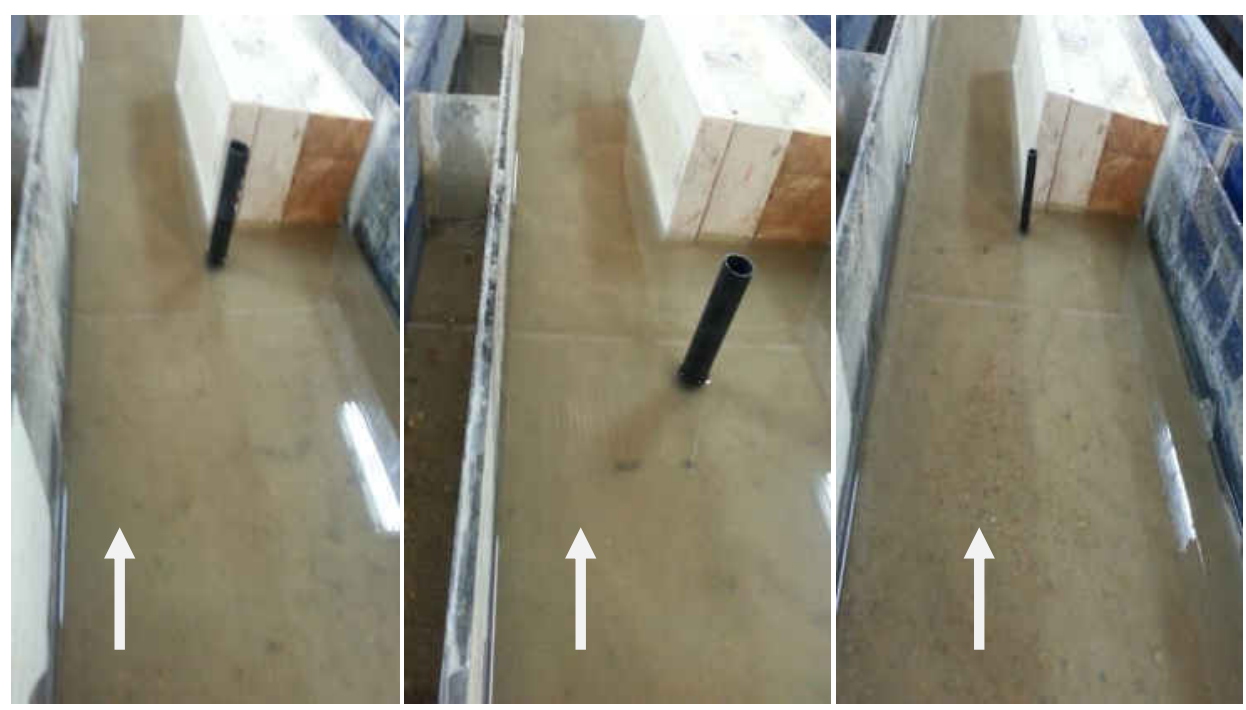

Photo 1. Different diameters and positions of pile

\section{The numerical model}

SSIIM is an abbreviation for simulation of sediment movements in water intakes with multi-block option empirical equations. The SSIIM program solves the Navier-Stokes equations with the $\mathrm{k}-\varepsilon$ on a three dimensional and general non-orthogonal grids. These equations are discretized with a control volume approach.An implicit solver is used, producing the velocity field in geometry. The velocities are used when solving the convection-diffusion equations for different sediment sizes. The Navier-Stokes equations for non-compressible and constant density flow can be modeled as:

$$
\frac{\partial \mathrm{U}_{\mathrm{i}}}{\partial \mathrm{t}}+\mathrm{U}_{\mathrm{j}} \frac{\partial \mathrm{U}_{\mathrm{i}}}{\partial \mathrm{x}_{\mathrm{j}}}=\frac{1}{\rho} \frac{\partial}{\partial \mathrm{x}_{\mathrm{j}}}\left[-\mathrm{p} \delta_{\mathrm{ij}}-\rho \overline{\mathrm{u}_{\mathrm{l}} \mathrm{u}_{\mathrm{j}}}\right](2)
$$

Where $U_{i}=$ the local velocity, $x_{j}=$ space dimension, $\mathrm{p}=$ pressre, $\delta_{\mathrm{ij}}=$ kronecker delta, $\rho=$ fluid density and $u_{i}=$ the average velocity.

The first term on the left side of the Equation (2) indicates the time variations; the second term is the convective term. The first term on the right-hand side is the pressure term and the second term on the right side of the equation is the Reynolds stress. This eq.is solved using finite discontinuing volume method.

A control-volume approach is used for discretization of the equations. The Reynolds stress is evaluated using turbulence model $\mathrm{k}-\varepsilon$.

$$
-\overline{\mathrm{u}_{\mathrm{i}} \mathrm{u}_{\mathrm{j}}}=v_{\mathrm{T}}\left(\frac{\partial \mathrm{u}_{\mathrm{i}}}{\partial \mathrm{x}_{\mathrm{j}}}+\frac{\partial \mathrm{u}_{\mathrm{j}}}{\partial \mathrm{x}_{\mathrm{i}}}\right)-\frac{2}{3} \mathrm{k} \delta_{\mathrm{ij}}(3)
$$

The first term on the right - hand side of the Equation (3) is the diffusive term in The Navier-Stokes equations.

The influence of rough boundaries on fluid dynamics is modeled through the inclusion of the wall law as given as follows: 


$$
\frac{\mathrm{U}}{\mathrm{U}_{*}}=\frac{1}{\mathrm{~K}} \ln \left(30 \mathrm{z} / \mathrm{K}_{\mathrm{S}}\right)(4)
$$

Where, ks equals to the roughness height, which calculated using Van Rijns (1987), K is von Karmen constant, $\mathrm{U}$ is the mean velocity, $\mathrm{U}_{*}$ is the shear velocity and $\mathrm{z}$ is the height above the bed.

\section{Model description}

A structured grid mesh on the $x-y-z$ plane was generated. As shown in Fig. (2), The Abutment was generated by specifying its ordinates, and then the grid interpolated using the elliptic grid generation method. However, the abutment was generated by blocking the area of the Abutment. The different ordinates of the pile were also specified, and then the pile was generated by blocking its area.

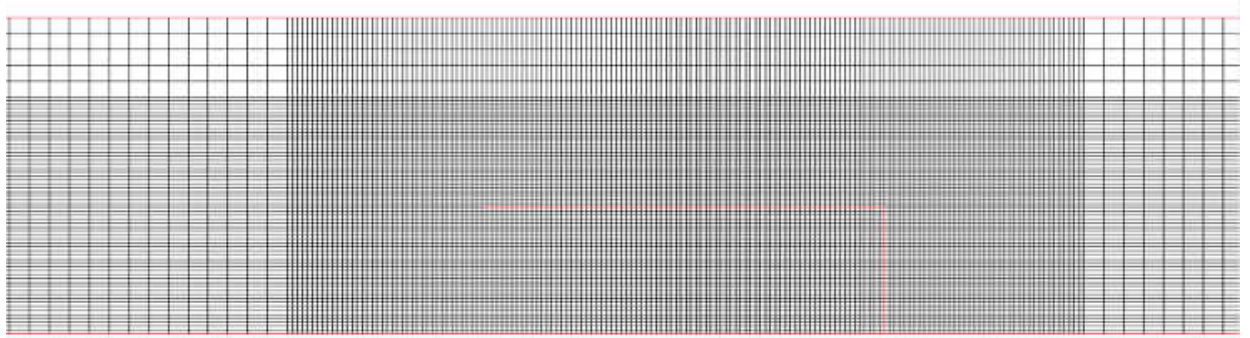

Fig. 2. Detailed view of the grid mesh

\section{Model verification}

Tests were first performed on the abutment without pile. A series of tests were carried out on the case of the abutment with upstream pile with different diameters and positions. Figure (3) shows experimental values of maximum scour depth as a ratio of the tail water depth, $\left(h_{s} / y_{t}\right)$ Experimental, versus the numerical values, $\left(h_{s} / y_{t}\right)$ Simulated, predicted by the 3D numerical model for the different three pile diameters used in this study. Figs.(4) and (5) illustrate the effect of the pile positions. It is noticeable that there were well agreement between the experimental and numerical values of maximum scour depth with an average correlation coefficient of 97\%. Fig.(6) shows a comparison between maps for case of abutment without pile and with case of abutment with upstream pile of $\mathrm{D} / \mathrm{B}=0.125$, $\mathrm{x} / \mathrm{B}=0.25, \mathrm{~b} / \mathrm{B}=1.0$.

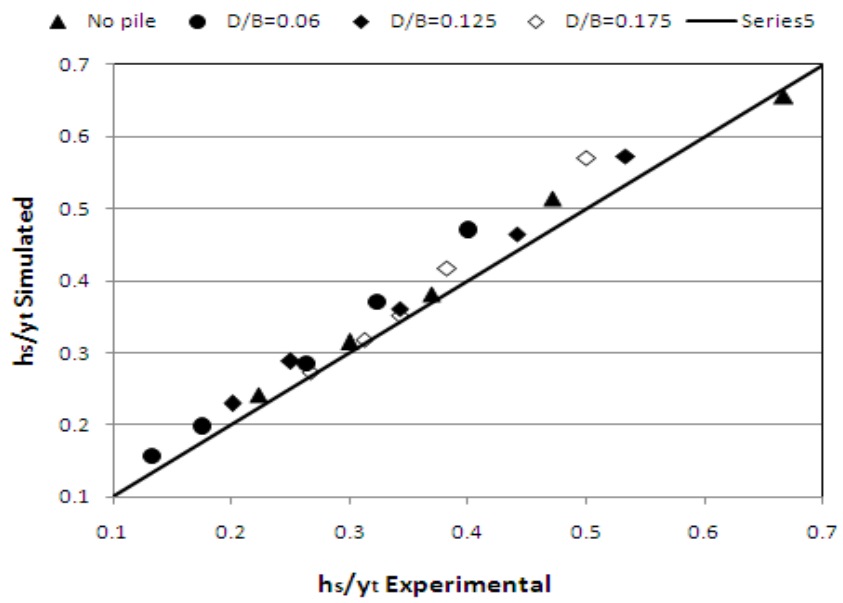

Fig. 3. Simulated versus experimental for $\left(h_{s} / y_{t}\right)$ for different pile diameters $(D / B)$. 


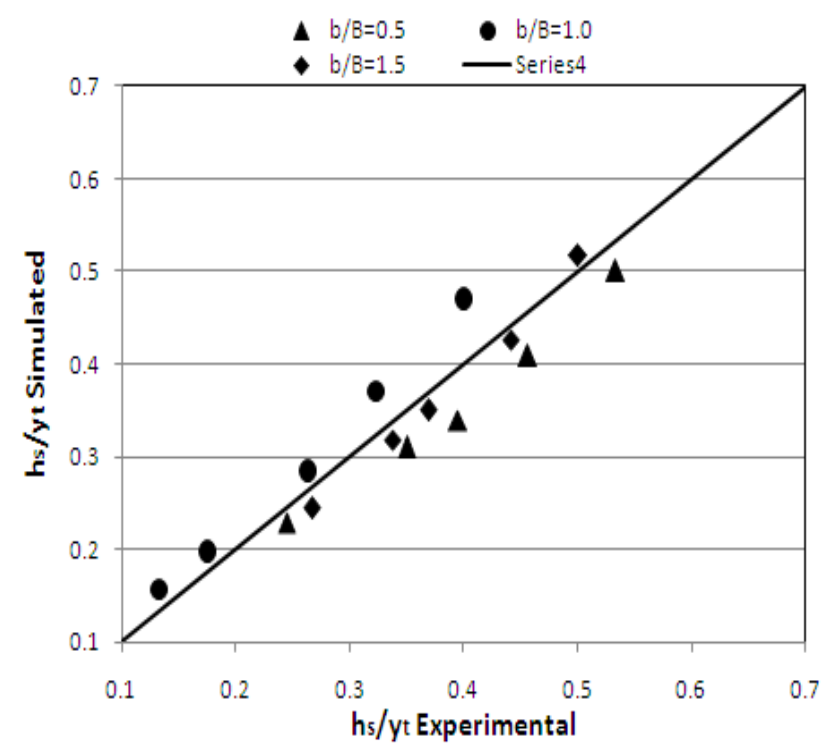

Fig. 4. Simulated versus experimental for $\left(\mathrm{h}_{\mathrm{s}} / \mathrm{y}_{\mathrm{t}}\right)$ for different positions of pile $(\mathrm{x} / \mathrm{B})$.

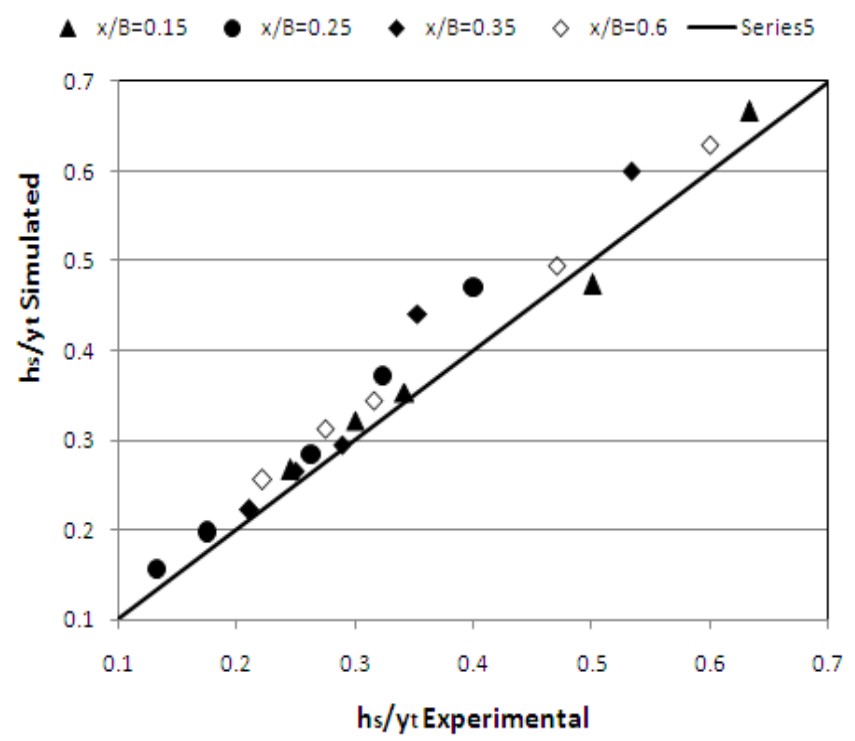

Fig. 5. Simulated versus experimental for $\left(\mathrm{h}_{\mathrm{s}} / \mathrm{y}_{\mathrm{t}}\right)$ for different positions of pile $(\mathrm{b} / \mathrm{B})$. 


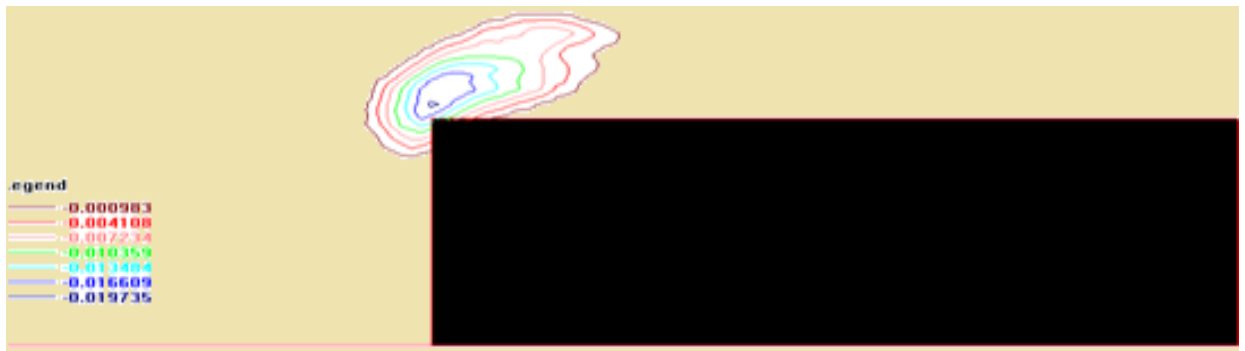

a)

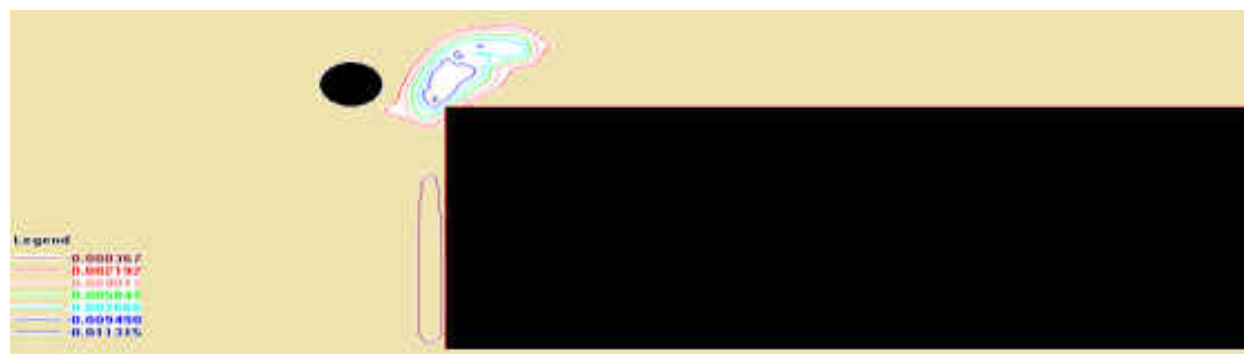

b)

Fig. 6. Scour contour maps for i) no pile, ii) $D / B=0.125, x / B=0.25, b / B=1$.

\section{Analysis}

\subsection{The effect of relative pile diameter $(D / B)$}

Fig. (7) shows the relationship between the tail Froude number $F_{t}$ and the maximum local scour depth around the bridge abutment $\mathrm{h}_{\mathrm{s}} / \mathrm{y}_{\mathrm{t}},\left(\mathrm{y}_{\mathrm{t}}\right.$, is the tail water depth) with and without a protective pile, different pile diameters were used $(\mathrm{D} / \mathrm{B}=0.06,0.125,0.175)$. This figure shows thatthe values of the relative scour depth $\left(\mathrm{h}_{\mathrm{s}} / \mathrm{y}_{\mathrm{t}}\right)$ increases as the tail Froude number increases. In addition, the relative scour depths produced by a protective pile are smaller than those without pile. This indicates that using pile decreases the relative scour depth. Therefore, pile seems to be effective upstream the abutment bridge by protecting upstream area of abutment. For $(\mathrm{D} / \mathrm{B}=0.175)$, the pile had a very slight effect on reducing the scour. Results show, that relative pile diameter of $(\mathrm{D} / \mathrm{B}=0.125)$ give a maximum reduction in scour depth with about $46 \%$.

\subsection{The effect of relative pile position $(x / B)$}

Results of Fig. (8) show the variation of $h_{s} / y_{t}$ with various positions of pile $(x / B=0.15$, $0.25,0.35,0.6)$.It could be seen that, under the condition of same flow and bed material, the relative scour depth of the scour hole around the abutment increases as $F_{t}$ increases. In addition, the relative scour depth minified to the minimal limit in case of $x / B=0.25$, it reduces the relative scour depth $\mathrm{h}_{\mathrm{s}} / \mathrm{y}_{\mathrm{t}}$, by about $48 \%$ compared to the no-pile case, which can be considered as the optimum position of the pile.

\subsection{The effect of relative pile position $(b / B)$}

Fig.(9)shows the variation of $h_{s} / y_{t}$ with various positions of pile $(b / B=0.5,1.0,1.5)$. Results show, that relative pile position of $\mathrm{b} / \mathrm{B}=1$.0give a maximum reduction in scour 
depth. The reduction in the relative scour depth around the abutment with aprotective pile with $(b / B=0.5,1.0,1.5)$ equal $20.8 \%, 41 \%, 31.3 \%$ of the relative scour depth around the abutment without pile.

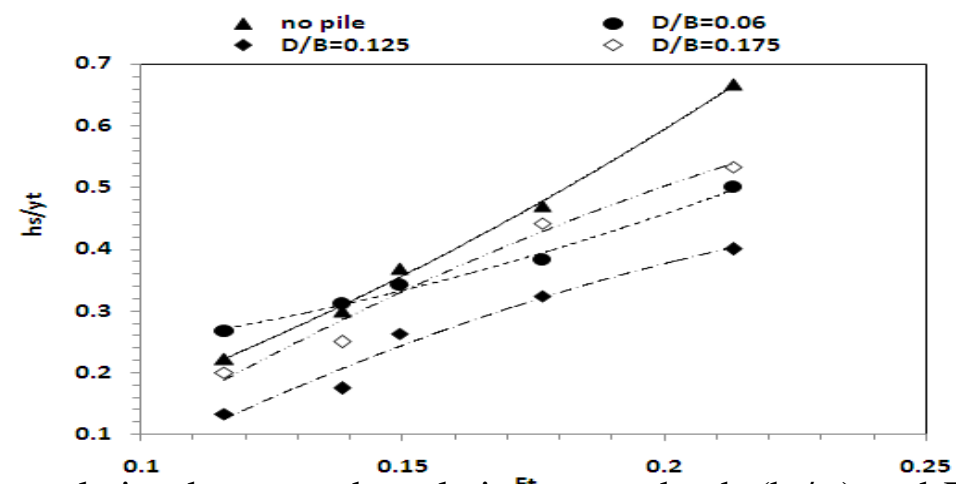

Fig. 7.The relation between the relative $\mathrm{E}^{\mathrm{t}}$ scour depth $\left(\mathrm{h}_{\mathrm{s}} / \mathrm{y}_{\mathrm{t}}\right)$ and Froude number $\mathrm{F}_{\mathrm{t}}$ for different pile diameters.

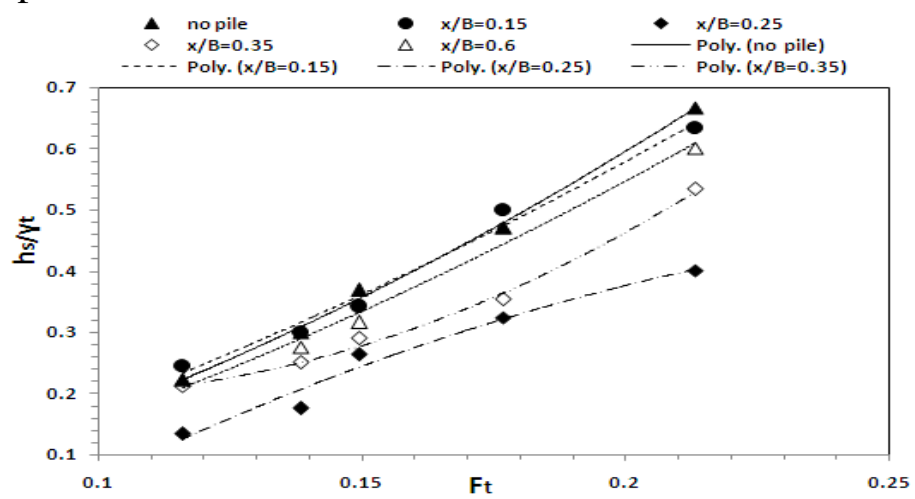

Fig. 8. The relation between the relative scour depth $\left(h_{s} / y_{t}\right)$ and Froude number $F_{t}$ for different pile positions $(\mathrm{x} / \mathrm{B})$.

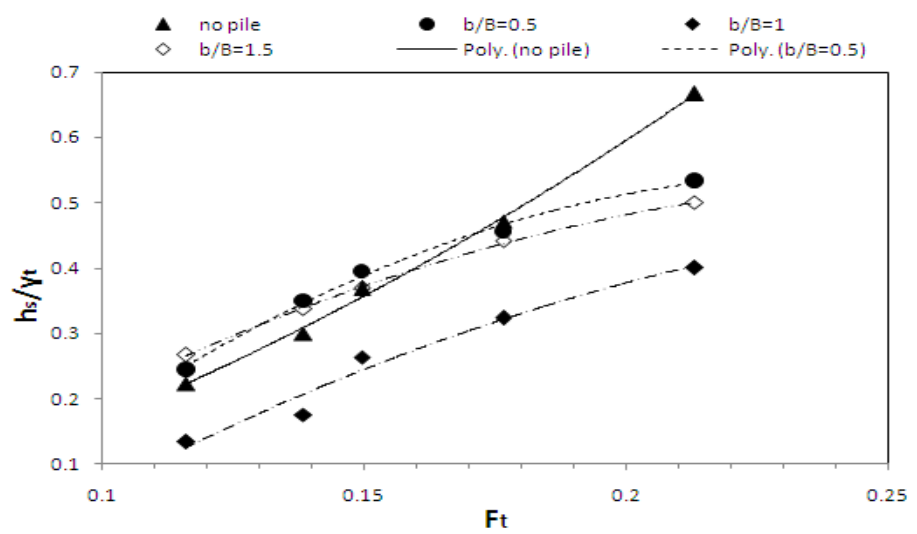

Fig. 9. The relation between the relative scour depth $\left(\mathrm{h}_{\mathrm{s}} / \mathrm{y}_{\mathrm{t}}\right)$ and Froude number $\mathrm{F}_{\mathrm{t}}$ for different pile positions $(\mathrm{b} / \mathrm{B})$. 
The presence of a pile upstream the abutment reduces collisions of water at the upstream face of the abutment and forces water to draw back to the bottom causing scour. But if the abutment is found in the area of the dead zone behind the pile, it is important to investigate the width of pile and its distance from the abutment because they have positive or negative impact on the activity of the movements of soil particles around the abutment. It is known from pervious researches that, the presence of a protective pile upstream the abutment and by the collision of water, it causes erosion around the pile and the soil particles begin in motion in the direction of flow. Depositions are occurred if water velocity decreased. So, the presence of pile causes a stagnant area works to reduce velocity and increase sedimentations in that area. For this, the balance between the movement of sedimentation resulting from the presence of the pile upstream the abutment and the activity of scour around it is a very important. The presence of the pile near enough the abutment may be increased the scour activity and the existing of pile u.s. the abutment had been a little effect and clear impact. When the pile exists far away the abutment it comes out from the area, where interaction between the pile and abutment doesn't exist, the result is playing each structure individually. This explains that the optimum case of pile is $(\mathrm{D} / \mathrm{B}=0.125, \mathrm{x} / \mathrm{B}=0.25, \mathrm{~b} / \mathrm{B}=1.0)$, it reduced the maximum scour depth by about $41 \%$.

Whenever the pile is away from the abutment in the lateral direction, sedimentations around the abutment decrease and thus the pile has a little impact, while silting increases in the contracted waterway.

\section{Statistical regression}

A statistical regression analysis is used for correlating the different dimensionless variables to develop an empirical equation for predicting the relative scour depth $h_{s} / y_{t}$. Based on the experimental data the developed equation can be expressed as follows;

$$
\frac{h_{s}}{y_{t}}=3.574 F_{t}-0.053 \frac{D}{y_{t}}-0.003 \frac{x}{y_{t}}-0.004 \frac{b}{y_{t}}-0.154
$$

The predicted values are plotted against the experimental values; also the residuals are plotted versus the predicted values as shown in figures (10) \& (11). The results showed well agreement between the experimental and predicted values of $h_{s} / y_{t}\left(R^{2}=0.91\right.$ and $R^{2}$ between residuals and predicted values is $9.15 \mathrm{E}^{-15}$.

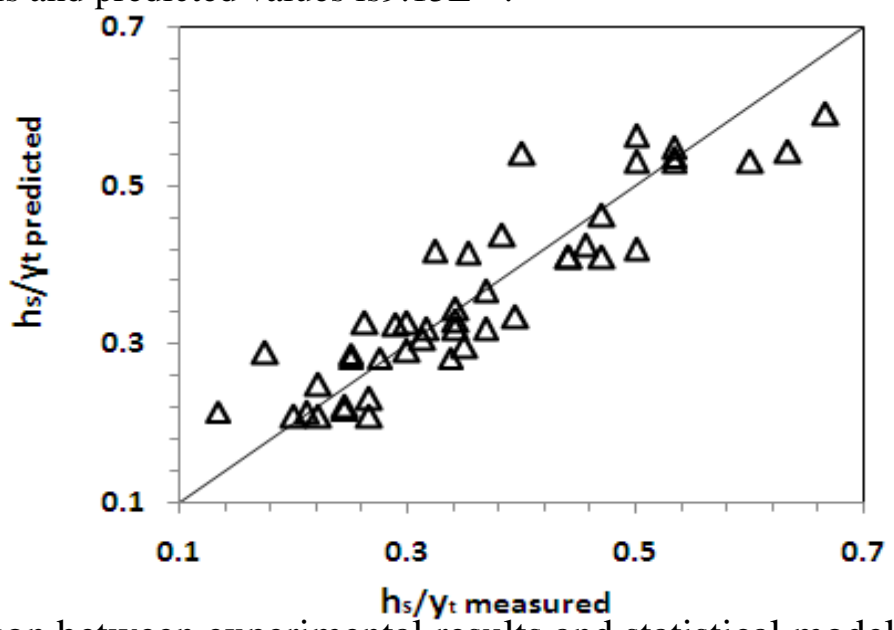

Fig. 10.Comparison between experimental results and statistical model (Eq. 5) results . 


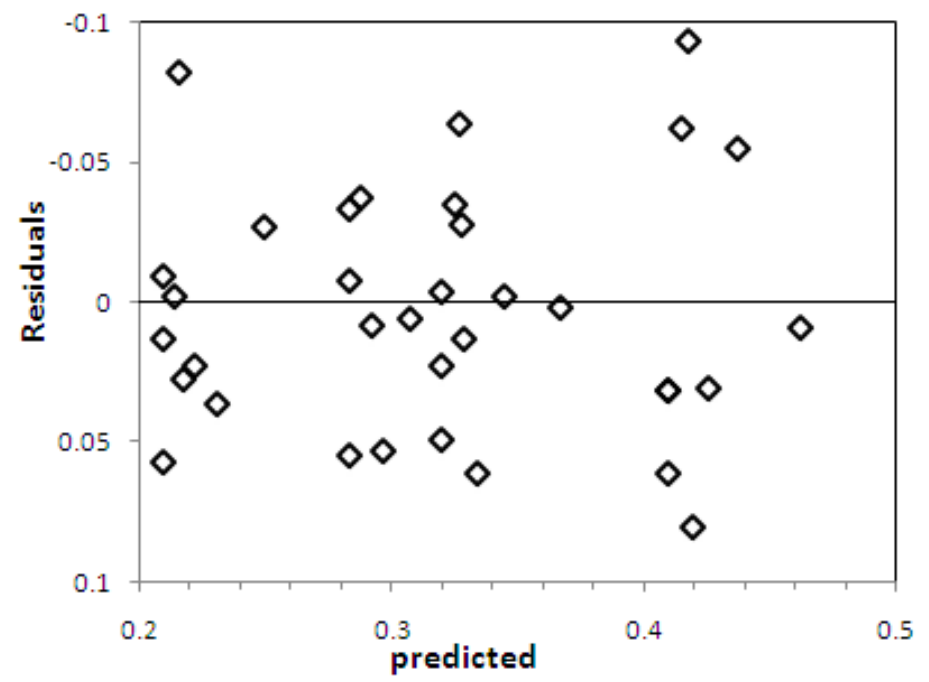

Fig. 11.Variations of residuals for different data sets with predicted data Eq. (5)

\section{Conclusion}

Experimental and numerical studies were conducted to investigate the scour around a bridge abutment. The characteristics of the scour hole have been shown to be affected by using a protective pile upstream the abutment. It was found that:

- Using of a pile upstream the abutment provide a benefit at reducing the maximum scour depth.

- A $\mathrm{D} / \mathrm{B}=0.125$, pile is very effective at reducing the scour depth when compared with $\mathrm{D} / \mathrm{B}=0,0.06,0.175$, by about $46 \%$ of the scour depth without pile.

- The pile located at $\mathrm{x}=0.25 \mathrm{~B}, \mathrm{~b}=\mathrm{B}$, just upstream the abutment reduces the relative scour depth $\mathrm{h}_{\mathrm{s}} / \mathrm{y}_{\mathrm{t}}$ by $41 \%$ compared to the no-pile case.

- The simulated results show the ability of the SSIIM program for modeling the local scouring at bridge abutments with and without pile with an average correlation coefficient of $97 \%$.

- The results of the proposed statistical equations are compared to the experimental measurements and an acceptable agreement has been found.

\section{REFERENCES}

[1] Abdel-Aal, G.M., Mohamed, Y.A.,Waheed, E.O., El-fooly, M.M., “ Local scour mitigation around bridge piles using protective plate (collar)", Scientific Bulletin, Faculty of Engineering, Ain Shams University, Cairo, Egypt, (2), 343-354, 2008.

[2] Abdel-Aal, G.M., Mohamed, Y.A., "The effect of collar size and shape on scour depth around bridge piers", 2010, Scientific Bulletin, Faculty of Engineering, Ain Shams University, Cairo, Egypt.

[3] Abouzeid, Gamal A. A., Mohamed, Hassan I., Ali, Shima M., "3-D numerical simulation of flow and clear water scour by interaction between bridges piers", Tenth international water technology conference, Alexandria, Egypt, 899-915, 2006.

[4] Abou-Seida, Mostafa, T.M.S, lsaeed, G.H., Elzahry, E.F.M., "Experimental investigation of abutment scour in sandy soil”, J. Appl. Sci. Res. 5(1), 57-65, 2009, Faculty of Engineering (Shoubra), Banha University, Egypt. 
[5] Alabi, P.D., "Time development of local scour at bridge pier fitted with a collar", 2006, Master degree thesis, University of Saskatchewan, Saskatoon, Saskatchewan, Canada.

[6] AlirezaMasjedi, Mahmood ShafaeiBejestan, AbdolkarimEsfandi,"Reduction of local scour at a bridge pier fitted with a collar in a 180 degree flume bend (Case study: oblong pier) ", Journal of Hydrodynamics, Science direct, 22(5), 669-673, 2010.

[7] Dey, S., Barbhuiya, A.K., "Velocity and turbulence in a scour hole at a vertical-wall abutment", Flow measurement and Instrumentation, 17, 13-21, 2006.

[8] Dou, X., "Numerical simulation of three-dimensional flow field and local scour at bridge crossings", 1997, Ph.D., Dissertation, University of Mississippi, Oxford, MS, U.S.A.

[9] Forde, M.C., McCann, D.M., Clark, M.R., Broughton, P.J., Brown, A. "Radar measurement of bridge scour, NDT \& E International, 32, 481-492, 1999.

[10] Hua Li, "Countermeasures against scour at bridge abutments", 2005, PhD Thesis, Michigan Technological University.

[11]Kose, O., Yanmaz, M.A., "Scouring reliability of bridge abutments", Aksaray University, Aksaray, Turkey, Middle East Technical University, Ankara, Turkey. TeknikDergi 21(1), 49194934, 2010.

[12] Kumar, A., Kothyari, U.C., Raju, K.G., "Flow structure and scour around circular compound bridge piers e A review", Journal of Hydro-environment research, 252-265, 2012.

[13] Macky, G.H., "Model testing of bridge abutment scour protection", 1986, Ministry of works and development.

[14] Mohamed, Y.A., Abdel-Aal, G.M., Nasr-Allah, H., Shawky, A.A., "Experimental and theoretical investigations of scour at bridge abutment", 2013, Journal of King Saud University, Engineering Sciences, In press.

[15] Morales, R., Ettema, R., "Insights from depth-averaged numerical simulation of flow at bridge abutments in compound channels", Department of Civil and Architectural Engineering University of Wyoming Laramie, WY 82071, 701, 231-7708, 2011.

[16] Mowafy, M.H., Fahmy, M.R., "The effect of constructing two adjacent bridges on the flow characteristics and local scour around bridge piers", Ain Shams university, Cairo, Egypt, 36(1), 129-141, 2001.

[17] Melville, B.W., "Discussion of local scour at bridge abutments", J. Hydraulic Eng., 118(4), 1069-1071, 1992.

[18] Najafzadeh, M., Barani, G.A., Azamathulla, H.M., "GMDH to predict scour depth around a pier in cohesive soils", Applied ocean research, 40, 35-41, 2013.

[19] Oslen, N.R.B., Melaaen, M.C., "Three-dimensional calculation of scour around cylinders", J. Hydraul. Eng. ASCE, 119, 1048-1054, 1993.

[20] Peng, W.U., Faye, H., Jueyi, S., "Impacts of ice cover on local scour around semi-circular bridge abutment”, Journal of Hydrodynamics, 26(1), 10-18, 2014.

[21] Richardson, J.E., Panching, V.G., "Three-dimensional simulation of scour- inducing flow at bridge piers", J. Hydraul. Eng. ASCE, 124, 530-540, 1998.

[22] Sui, J., Afzalimehr, H., Samani, A.K., Mahrnoosh, M. "Clear-water scour around semielliptical abutments with armored beds", International Journal of sediment research, 25, 233$245,2010$.

[23] Taymaz, E., Amir, A.D., Mohammad, R.P., Tetsuya, S., "Numerical simulation of skewed slot effect on local scour reduction", Journal of Water Sciences Research, 3(1), 69-80, 2011.

[24] Tseng, M.H., Yen, C.L., Song, C.S., "Computation of three dimensional flow around square and circular piers", Int. J., Numer. Meth. Fluids, 122, 120-128, 2000.

[25]Zarrati., A.M., Mohammed, R., Shafaie, A., Latifi, M., "Scour countermeasures for cylindrical piers using riprap", Journal of Sediment Research, 25, 313-322, 2010.

[26]Zarrati, A.M., Gholami, H., Mashahir, M. B., "Application of collar to control scouring around rectangular bridge piers”, J. Hydraul. Res., IAHR, 42(1), 97-103, 2004.

[27]Zarrati, A.M., Nazariha, M., Mashahir, M. B., "Reduction of local scour in the vicinity of bridge pier groups using collars and riprap", J. Hydraul. Eng., ASCE, 132(2), 154-162, 2006. 


\section{التحكم فى النحر حول كتف الكوبرى باستخدام خازوق حماية}

\section{ايمان على حسين على النخيلى}

مدرس بقسم هندسة المياه و المنشآت المائية كلية الهندسة- جامعة الزقازيق

\section{الملخص العزبى}

يوجد العديد من الطرق المختلفة التى تناولت التحكم فى مشكلة النحر حول كتف الكوبرى.و فى هذه الدر اسة

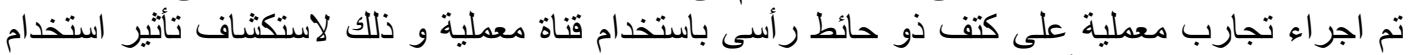

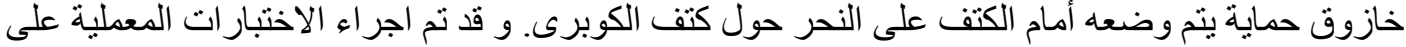

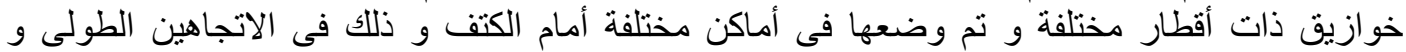

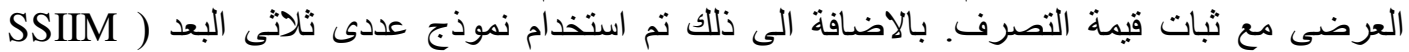

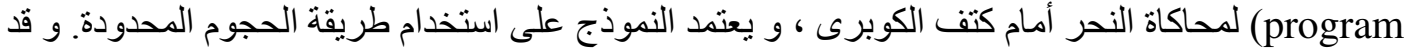

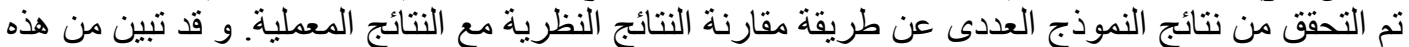

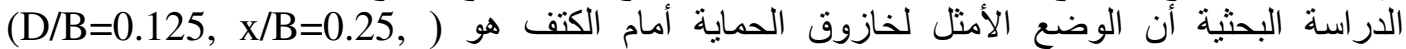

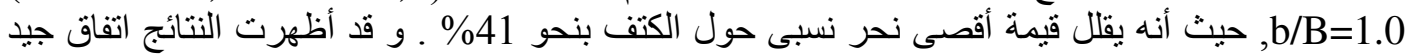

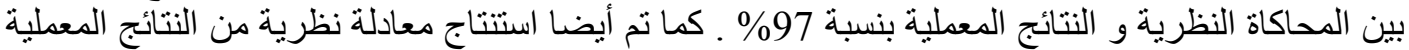
لمحاكاة أقصى عمق نحر حول الكتف مع وجود خازوق الحمثة الحماية. 